\title{
Chemical characterisation and source identification of atmospheric aerosols in the Snowy Mountains, south-eastern Australia
}

\author{
Carol V. Tadros a,b,*, Jagoda Crawford ${ }^{\mathrm{a}}$, Pauline C. Treble ${ }^{\mathrm{a}, \mathrm{b}}$, Andy Baker ${ }^{\mathrm{b}}$, David D. Cohen ${ }^{\mathrm{a}}$, Armand J. Atanacio ${ }^{\mathrm{a}}$, \\ Stuart Hankin ${ }^{\mathrm{a}}$, Regina Roach ${ }^{\mathrm{c}}$ \\ a Australian Nuclear Science and Technology Organisation, Locked Bag 2001, Kirrawee DC, NSW 2232, Australia \\ b Connected Waters Initiative Research Centre, UNSW Australia, Sydney, NSW, Australia \\ c NSW National Parks and Wildlife Service, Sydney, NSW, Australia
}

\section{H I G H L I G H T S}

- First PM2.5 dataset (2013-2017) for the Snowy Mountains alpine region, SE Australia

- Sources of PM2.5: automobile, secondary sulfate, smoke, soil and aged sea salt

- Long-range transport of $\mathrm{Na}$ and aeolian dust impacts this remote inland site.

- Drought and El Niño conditions enhanced smoke and soil aerosol loadings.

\section{A R T I C L E I N F O}

\section{Article history:}

Received 3 January 2018

Received in revised form 19 February 2018

Accepted 19 February 2018

Available online 24 February 2018

Editor: Jianmen Chen

\section{Keywords:}

$\mathrm{PM}_{2.5}$

Positive matrix factorisation

Long-range transport

Snowy Mountains

El Niño

Aeolian dust
G R A P H I C A L A B S T R A C T

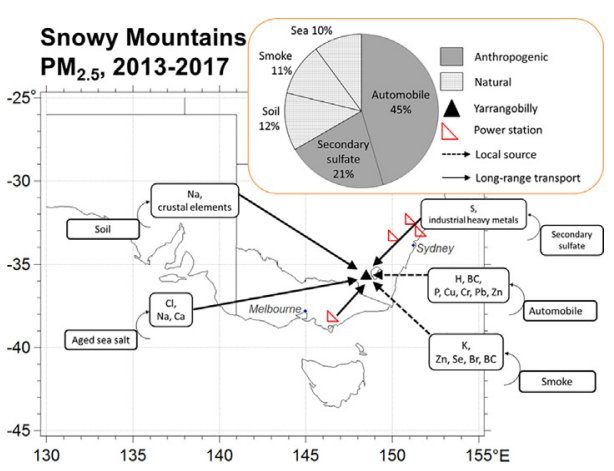

\begin{abstract}
A B S T R A C T
Characterisation of atmospheric aerosols is of major importance for: climate, the hydrological cycle, human health and policymaking, biogeochemical and palaeo-climatological studies. In this study, the chemical composition and source apportionment of $\mathrm{PM}_{2.5}$ (particulate matter with aerodynamic diameters less than $2.5 \mu \mathrm{m}$ ) at Yarrangobilly, in the Snowy Mountains, SE Australia are examined and quantified. A new aerosol monitoring network was deployed in June 2013 and aerosol samples collected during the period July 2013 to July 2017 were analysed for 22 trace elements and black carbon by ion beam analysis techniques. Positive matrix factorisation and back trajectory analysis and trajectory clustering methods were employed for source apportionment and to isolate source areas and air mass travel pathways, respectively. This study identified the mean atmospheric $\mathrm{PM}_{2.5}$ mass concentration for the study period was $(3.3 \pm 2.5) \mu \mathrm{g} \mathrm{m} \mathrm{m}^{-3}$. It is shown that automobile $(44.9 \pm$ $0.8) \%$, secondary sulfate $(21.4 \pm 0.9) \%$, smoke $(12.3 \pm 0.6) \%$, soil $(11.3 \pm 0.5) \%$ and aged sea salt $(10.1 \pm$ $0.4) \%$ were the five $\mathrm{PM}_{2.5}$ source types, each with its own distinctive trends. The automobile and smoke sources were ascribed to a significant local influence from the road network and bushfire and hazard reduction burns, respectively. Long-range transport are the dominant sources for secondary sulfate from coal-fired power stations, windblown soil from the inland saline regions of the Lake Eyre and Murray-Darling Basins, and aged sea salt from the Southern Ocean to the remote alpine study site. The impact of recent climate change was recognised, as elevated smoke and windblown soil events correlated with drought and El Niño periods. Finally, the overall
\end{abstract}

\footnotetext{
* Corresponding author at: Australian Nuclear Science and Technology Organisation, Locked Bag 2001, Kirrawee DC, NSW 2232, Australia.

E-mail address: Carol.Tadros@ansto.gov.au (C.V.Tadros).
} 
implications including potential aerosol derived proxies for interpreting palaeo-archives are discussed. To our knowledge, this is the first long-term detailed temporal and spatial characterisation of $\mathrm{PM}_{2.5}$ aerosols for the region and provides a crucial dataset for a range of multidisciplinary research.

Crown Copyright @ 2018 Published by Elsevier B.V. All rights reserved.

\section{Introduction}

The main aerosol sources which influence the atmosphere of the Australian continent include windblown soil-dust, sea-salt, biomass burning, and biogenic secondary organic aerosols from volatile organic aerosols (Rotstayn et al., 2009). Aerosols are solid and/or liquid particles suspended in air (Pöschl, 2005). These particles may be emitted directly into the atmosphere from i) natural sources, such as: biogenic volatile organic compounds emitted from vegetation, sea-salt, soil-dust, volcanoes, biomass burning; or ii) anthropogenic sources, such as: coalburning, metal smelting, vehicle emissions (Colbeck and Lazaridis, 2014). Once in the atmosphere, the aerosols are transported downwind of their source area, during which time chemical reactions can occur, resulting in the formation of secondary aerosols from precursor gasses such as $\mathrm{SO}_{2}$ and $\mathrm{NO}_{\mathrm{x}}$ (e.g. Squizzato et al., 2013; Suni et al., 2008). Thus aerosols contain chemically distinct concentrations of trace metals, characteristic of their supply source, air mass history and geographical proximity to coastal, desert, rural, industrial and polar emission sources.

Aerosols suspended in the atmosphere are known to impact the climate system. Aerosol particles have a direct radiative forcing effect on the Earth's surface and atmosphere, because they can absorb or scatter incoming solar radiation. When solar radiation is reflected back to space, a smaller amount of solar energy reaches the ground and this has a cooling effect on the regional and global climate, whereas some aerosol particles can absorb solar radiation and this warms the atmospheric layer. Aerosols also have indirect radiative forcing effects on the climate through modifying the formation and microphysical cloud properties, leading to a cooler climate. Acting as condensation nuclei, soluble aerosols can increase the condensation moisture in clouds by increasing the droplet number concentration and therefore cloud albedo, or the reflection of solar radiation to space. Aerosols also decrease the droplet size in clouds, suppressing precipitation (and affecting the hydrological cycle), which may also lead to an increase in cloudiness and reflection of solar radiation. These direct and indirect aerosol effects on the climate are determined by aerosol particle size, structure and chemical composition (Pöschl, 2005).

Air quality is the most visible effect of aerosols in the environment, affecting visibility, aviation and road traffic safety as well as human health. Fine particulate matter with an aerodynamic diameter smaller than $2.5 \mu \mathrm{g}\left(\mathrm{PM}_{2.5}\right)$ can foster acute and chronic diseases (Pope III et al., 2009), hence to reduce air pollution, policy interventions, targeting concentration limits and air quality guidelines, are established based on monitoring data (WHO, 2006). Atmospheric deposition of aerosols is also of specific interest in ecosystem biogeochemistry (Mahowald, 2011). Aerosols provide trace metals that are essential for productivity in terrestrial (Chadwick et al., 1999) and marine ecosystems (Jickells, 1995). Alternatively they can have a negative impact, for example acid rain, due to atmospheric sulfate or nitrate deposition, by enhancing the leaching of nutrients from land ecosystems (Likens, 2010 ) or results in ocean acidification in coastal regions (Doney et al., 2007). Depositing aerosols are also known to alter the physical and chemical properties of soils and sediments (Simonson, 1995; Hesse and McTainsh, 2003; Rutlidge et al., 2014). In addition the deposition of trace metals from aerosols in natural archives is important in palaeoclimate studies (Sigl et al., 2015). The concentration of aerosols deposited in soils, sediments, peat, speleothems and glaciers have been used as palaeo proxy indicators of climate and environmental changes (Rea, 1994; Kohfeld and Harrison, 2001; Frisia et al., 2005; Frappier, 2006; Marx et al., 2011; Allan et al., 2015; Ridley et al., 2015). Thus an understanding of the composition, source and transport of atmospheric aerosols are highly relevant for studies in various disciplines including climate processes, human health and policies, terrestrial and marine biogeochemical cycling and palaeo-climatology.

Our study site is located in Kosciuszko National Park, a high elevation-alpine site in mainland Australia (1059 m above sea level). The location of the study site is a sensitive monitor for past hydroclimate and environmental change as it is a region prone to ash input from fire activity and wind-blown dust deposition, as it is located within the south-eastern pathway of dust transport from active emission sources in central Australia (Shao et al., 2011). The site is also strategically unique in Australia, being a remote inland site; it is conducive to study the impact of long-range atmospheric transport from regional and natural emission sources.

The impetus for the current study is to define the chemical characteristics and input sources and gain a better understanding of transport processes of atmospheric particulate matter to karst in the Snowy Mountains alpine region, Yarrangobilly, SE Australia. This study was conducted as part of a wider project to reconstruct past environmental change from cave deposits (speleothems) in order to better understand past variability in climate, fire history and environmental change in the Snowy Mountains region. Trace elements are one of the commonly used proxies for providing information on the hydro-climate regime surrounding the depositional conditions in sediments and carbonate rock archives. As atmospheric aerosols are a direct source of trace elements, constraining the sources of trace elements may be highly relevant for the reconstruction of past environmental change from speleothems. Although the atmosphere may supply a significant source of elements to the soil and hence drip-waters, less attention has been placed on quantifying the atmospheric input from various sources above the cave. Dredge et al., 2013 highlighted that aerosols brought into the cave by air currents are a potential source of elements for speleothem deposition, however neither the source of aerosols nor the atmospheric processes associated with them were investigated. Hence there is a current knowledge gap in our understanding of the holistic role of atmospheric input, particularly aerosols, as a potential source of elements that have been transported in the cave via infiltrating drip-water and incorporated into speleothem calcite.

This paper presents the first high resolution four-year $\mathrm{PM}_{2.5}$ dataset for the region. Ion beam analysis (Cohen et al., 1996) was used to identify the elemental composition of the $\mathrm{PM}_{2.5}$ samples, following which positive matrix factorisation (PMF; Paatero and Tapper, 1994) was applied to identify the contributing sources. Additionally, long-range source contribution regions to this remote inland site were identified using backward air mass trajectory calculations. To compliment the study, results were also compared to one of the global "baseline" atmospheric measurement sites at Cape Grim in Tasmania Australia, a remote coastal site that receives airflow predominately from the Southern Ocean and therefore with little impact from regional anthropogenic influences. The current data set is important for achieving a better understanding of the composition of atmospheric aerosols from natural and anthropogenic origin and from local and long-range transported sources in the Snowy Mountains. In essence, this work will provide a benchmark to understand the local and regional dynamics of aerosol sources, providing the most extensive aerosol baseline dataset for application in other studies regionally. 


\section{Methods}

\subsection{Study site and area description}

An aerosol $\mathrm{PM}_{2.5}$ monitoring station was deployed on 26 June 2013 above Jillabenan Cave, NSW, Australia ( $35^{\circ} 43^{\prime} \mathrm{S}, 148^{\circ} 29^{\prime} \mathrm{E}$; Fig. 1a), $2.5 \mathrm{~m}$ from an existing weather station and $170 \mathrm{~m}$ from Harrie Wood Cave, which is the location of the cave drip water monitoring sites (Tadros et al., 2016). The aerosol sampling site is located within the Yarrangobilly Caves karst system and is situated in the northern part of Kosciuszko National Park, in the Snowy Mountains region of south- eastern New South Wales. Access to the Yarrangobilly Caves is via the Snowy Mountains Highway (Fig. 1a). At an elevation of $1287 \mathrm{~m}$ above sea level (a.s.l.) this road, and the cave site, receives snowfall during the winter months. The sampler is at an altitude of $1059 \mathrm{~m}$ a.s.l and is on the western side of the Great Dividing Range (Fig. 1b). The Great Dividing Range, a series of plateaus, extends from Cape York Peninsula in northern Queensland southward to Victoria. It ranges in altitude from $300 \mathrm{~m}$ to $2228 \mathrm{~m}$ a.s.l; the height of Mt. Kosciusko and the highest point on the Australian mainland. The remainder of the continent has low topographical relief, where the average elevation is less than $300 \mathrm{~m}$. Hence the location of the study site is important as it lies
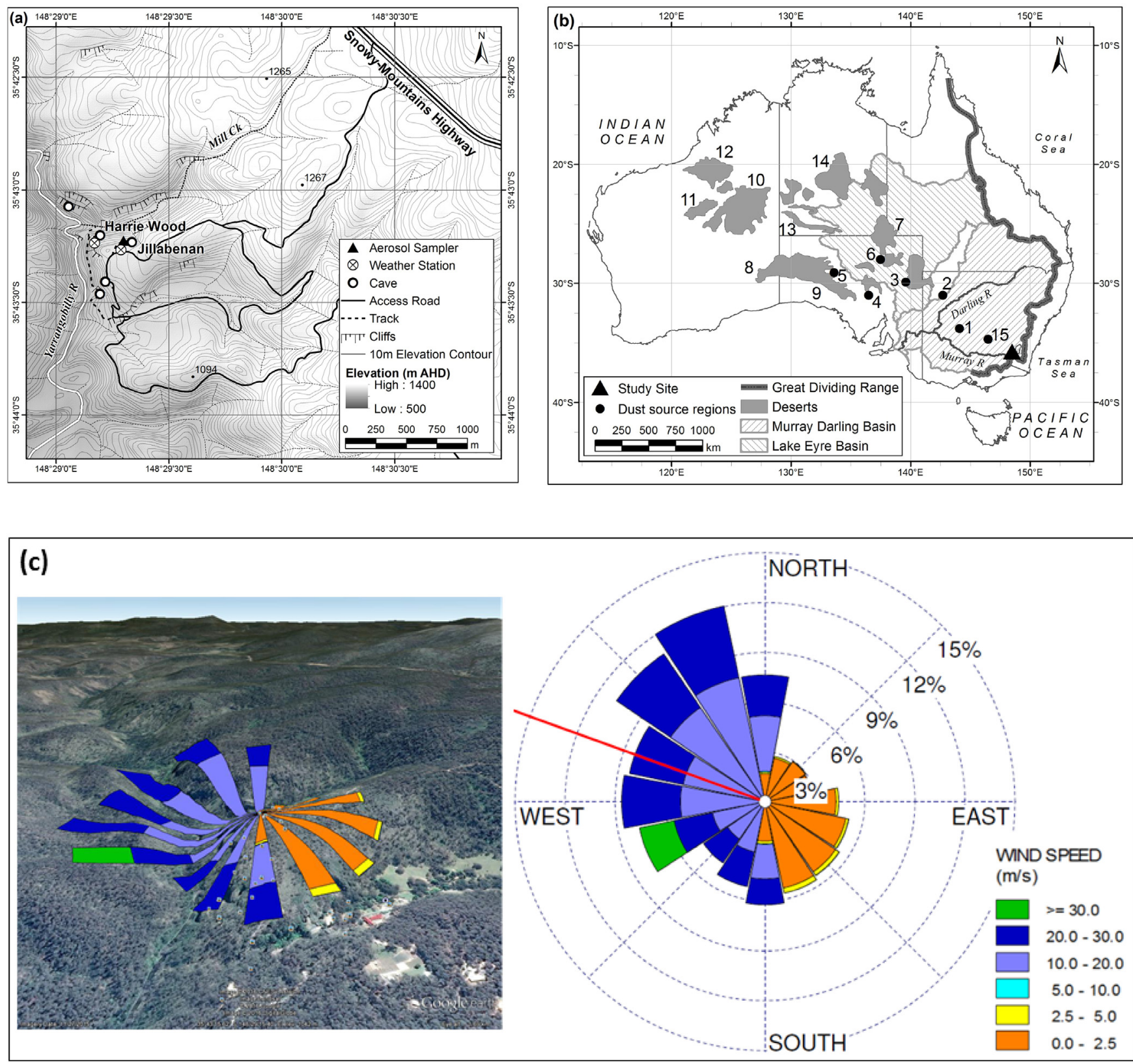

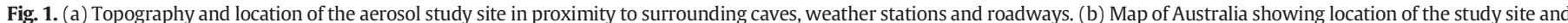

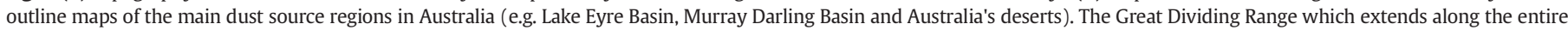

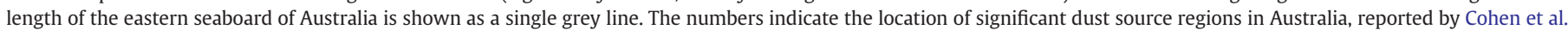

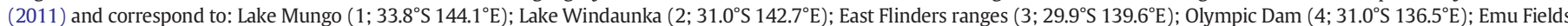

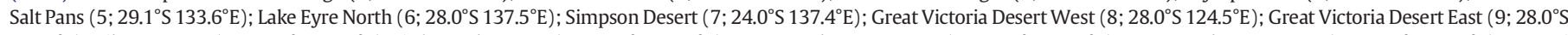

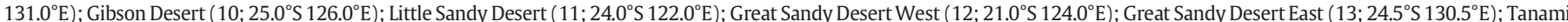

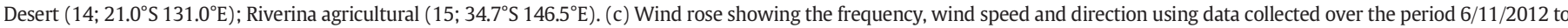

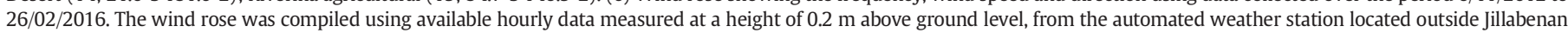
Cave. The mean wind direction is shown as a red vector. 
south-east of the Lake Eyre drainage basin and Murray Darling basin, a large area of persistent dust activity (Prospero et al., 2002) as well as great deserts in the western plateau (Fig. 1b).

The wind rose for our site, based on hourly wind data (Fig. 1c), shows that on an annual basis approximately $30 \%$ of the winds is from the northwest quadrant (WNW, NW and NNW). The mean wind direction is $290^{\circ}$ and for $21 \%$ of the time, wind blows from the WNW. During summer, onshore winds from the south-southeast are dominant, while during winter, stronger inland winds from the north-northwest direction dominate.

\subsubsection{Sampling}

A standard IMPROVE $\mathrm{PM}_{2.5}$ cyclone based aerosol sampling unit, operating at $221 \mathrm{~min}^{-1}$ and at a height of $2.0 \mathrm{~m}$ above ground level (agl; Cohen et al., 1996), was used to collect two aerosol samples per week. Between 03/07/2013 to 02/07/2017, $\mathrm{PM}_{2.5}$ samples were collected on Sunday and Wednesday from 24:00 to 24:00 Australian Eastern Standard Time the next day. Bulk aerosol samples were collected on $25 \mathrm{~mm}$ diameter stretched Teflon filters, approximately $250 \mu \mathrm{g} \mathrm{cm}^{-2}$ thick before exposure (pore size: $3.0 \mu \mathrm{m}$; PALL life sciences). A data gap between January and mid-March 2015 was due to field access restrictions.

\subsubsection{Chemical analysis}

The collected aerosol samples were analysed on a 2 MV STAR accelerator using ion beam analysis techniques: Proton Induced X-ray Emission Analysis (PIXE), Proton Induced Gamma-ray Emission Analysis (PIGE), Proton Elastic Scattering Analysis (PESA) and Rutherford Back Scattering Analysis (RBS) at ANSTO (Cohen et al., 1996; Cohen, 1998; Cohen et al., 2004a; Cohen et al., 2004b). PIXE provides data for selected elements between $\mathrm{Al}$ and $\mathrm{Pb}$ while PIGME, PESA and RBS were used to provide information on elements lighter than $\mathrm{Al}$. The four techniques were applied simultaneously using an $8 \mathrm{~mm}$ diameter beam of 2.6 $\mathrm{MeV}$ protons and the concentrations ( $\mathrm{ng} \mathrm{m}^{-3}$ ) of: $\mathrm{H}, \mathrm{N}, \mathrm{Na}, \mathrm{Al}, \mathrm{Si}$, $\mathrm{P}, \mathrm{S}, \mathrm{Cl}, \mathrm{K}, \mathrm{Ca}, \mathrm{Ti}, \mathrm{V}, \mathrm{Cr}, \mathrm{Mn}, \mathrm{Fe}, \mathrm{Co}, \mathrm{Ni}, \mathrm{Cu}, \mathrm{Zn}, \mathrm{Se}, \mathrm{Br}$ and $\mathrm{Pb}$, in the fine particles sampled were determined. Elements including $\mathrm{Mg}$ and Ba could not be measured analytically in the aerosol samples due to a low signal-noise ratio (Bird and Williams, 1989; Bird, 1990). Additionally, black carbon (BC) concentrations were determined using a laser HeNe absorption system, assuming a mass adsorption coefficient of $7 \mathrm{~m}^{2} \mathrm{~g}^{-}$ 1 (Taha et al., 2007).

\subsection{Data analysis}

\subsubsection{Chemical mass closure}

Following Malm et al., 1994, the degree of mass closure, ratio of the reconstructed chemical mass compared to the gravitational mass for each filter was evaluated, by employing the following overall equation:

Reconstructed mass $(\mathrm{RCM})=$ Salt + Ammonium sulfate + Soil

$$
+ \text { Smoke }+ \text { Organics }+ \text { BC }
$$

Estimates of each source component are defined by Eqs. (2)-(6) below:

Salt $=2.54[\mathrm{Na}]$

Ammonium sulfate $=4.125[\mathrm{~S}]$

Soil $=2.20[\mathrm{Al}]+2.49[\mathrm{Si}]+1.63[\mathrm{Ca}]+1.94[\mathrm{Ti}]+2.42[\mathrm{Fe}]$

Smoke $=[\mathrm{K}]-0.6[\mathrm{Fe}]$

Organics $=11([\mathrm{H}]-0.25[\mathrm{~S}])$

where: [ ] represents the elemental concentration, and a reconstructed vs. measured $\mathrm{PM}_{2.5}$ mass concentration correlation $\left(\mathrm{r}^{2}\right)$ greater than 0.7 is required for accurate source apportionments made by PMF.

\subsubsection{Source apportionment model: $P M F$}

Elemental source fingerprints and their contributions to the total $\mathrm{PM}_{2.5}$ at the sampling site were resolved from the measurements by applying PMF (Paatero and Tapper, 1994). PMF is a receptor modeling technique; whereby a multivariate statistical technique was applied to the complete dataset. The receptor model is an independent technique using the monitored aerosol chemical data only i.e. a priori information about the sources from the reconstructed chemical mass in Section 2.2.1 is not required (Viana et al., 2008). It is based on the principle that mass and species conservation can be assumed (Hopke et al., 2006), and where key elements in each factor are used to determine source profiles represented by that factor. In this application, the PMF program was used (Paatero and Tapper, 1994). PMF solves the standard bi-linear factor analysis model which can be specified as (Paatero, 2010):

$X=G F+E$

where $X$ is a matrix of measured elements, $G$ and $F$ are factor matrices to be determined, and $E$ is a matrix of residuals. This can also be written as:

$x_{i, j}=\sum_{k=1}^{p} g_{i, k} f_{k, j}+e_{i, j}$

Assuming $n$ observations are available of $m$ elements, then $X$ is an $n$ by $m$ matrix, i.e. $x_{i, j}$ represents the concentration of element $j$ in the $i$ th sample. PMF then determined the two factor matrices $\mathrm{G}$ and $\mathrm{F}$; if $p$ sources are contribution to the measurements, $G$ is an $n$ by $p$ matrix containing the contribution from each source to each sample, and $F$ is a $p$ by $m$ matrix containing the source fingerprints.

The matrices $\mathrm{G}$ and $\mathrm{F}$ are determined using an optimisation process which minimises the function $\mathrm{Q}$, while the resolved factor elements remain non-negative:

$Q=\sum_{i=1}^{n} \sum_{j=1}^{m} \frac{e_{i, j}^{2}}{s_{i, j}^{2}}$

where $s_{i, j}$ is a specified error of the form (Cohen et al., 2010):

$s_{i, j}=M D L_{i, j}+$ Error $_{i, j} \max \left(\left|x_{i, j}\right|,\left|y_{i, j}\right|\right)$

where $M D L_{i, j}$ is the minimum detectable limit, Error $_{i, j}$ is the statistical error, and $y_{i, j}$ is the fitted value i.e. $\mathrm{Y}=\mathrm{GF}$.

\subsubsection{Back trajectory analysis}

The contribution of dust from inland Australia transported to the monitoring site by west to north-westerly prevailing winds was resolved by applying the method outlined in Cohen et al. (2011). Fifteen possible dust source regions were selected and each region was represented as a rectangular grid cell which best approximated the extent of the desert region. The name and position of each grid cell is indicated in Fig. 1b. and the grid size used to represent the desert regions about their midpoints, is listed in Table 3 of Cohen et al. (2011). Next, for days with outlier soil concentrations, 10-day hourly back trajectory analyses were calculated using HYSPLIT (HYbrid Single-Particle Lagrangian Integrated Trajectory; Draxler et al., 2016; Stein et al., 2015) to generate density maps and identify the number of grid intersection points i.e. the relative impact of each source region to the dust fingerprint. Additionally, for all other sources, 10-day hourly back trajectory analyses were conducted for outlier days, specifically where the source concentration exceeded the mean by two standard deviations, and density maps were produced to identify source regions. Back trajectory density maps were generated, for which the horizontal position of the back trajectory (or trajectory endpoint) was determined every $30 \mathrm{~min}$. The region of interest was sub-divided into grid cells of $0.5^{\circ}$ by $0.5^{\circ}$ dimension, and if a back trajectory endpoint landed in the grid cell, a 


\section{Table 1}

Mean, standard deviation (SD), maximum values and MDLs for elemental species $\left(\mathrm{ng} \mathrm{m}^{-3}\right)$ and $\mathrm{PM}_{2.5}\left(\mu \mathrm{g} \mathrm{m}^{-3}\right)$ determined over Jillabenan Cave between July 2013 and July 2017 compared with those at Cape Grim (from April 1998 to June 2016).

\begin{tabular}{|c|c|c|c|c|c|c|c|c|}
\hline \multirow[t]{2}{*}{ Species } & \multicolumn{4}{|c|}{ Jillabenan Cave $(n=357)$} & \multicolumn{4}{|c|}{ Cape Grim $(n=1858)$} \\
\hline & $\begin{array}{l}\text { Mean } \\
(\mathrm{ng} \\
\left.\mathrm{m}^{-3}\right)\end{array}$ & SD & $\max$ & $\begin{array}{l}\text { MDLs } \\
(\mathrm{ng} \\
\left.\mathrm{m}^{-3}\right)\end{array}$ & $\begin{array}{l}\text { Mean } \\
(\mathrm{ng} \\
\mathrm{m}^{-3} \text { ) }\end{array}$ & SD & Max & $\begin{array}{l}\text { MDLs } \\
(\mathrm{ng} \\
\left.\mathrm{m}^{-3}\right)\end{array}$ \\
\hline $\mathrm{H}$ & 137 & 116 & 3614 & 1.97 & 85 & 94 & 1101 & 1.97 \\
\hline $\mathrm{N}$ & 132 & 179 & 3237 & 31.46 & 144 & 236 & 2366 & 23.42 \\
\hline $\mathrm{Na}$ & 178 & 88 & 942 & 27.75 & 1009 & 710 & 4866 & 7.21 \\
\hline $\mathrm{Al}$ & 14.0 & 9.7 & 139.5 & 1.31 & 3.9 & 7.5 & 219 & 1.84 \\
\hline $\mathrm{Si}$ & 38.6 & 27.6 & 398.9 & 0.77 & 13.0 & 23.3 & 598 & 0.96 \\
\hline $\mathrm{P}$ & 1.2 & 0.4 & 8.2 & 0.64 & 3.4 & 77.0 & 2455 & 1.05 \\
\hline$S$ & 179 & 83.8 & 779 & 0.57 & 233 & 159 & 1401 & 0.80 \\
\hline $\mathrm{Cl}$ & 54.0 & 48.6 & 1201 & 0.57 & 1520 & 1086 & 7251 & 0.98 \\
\hline $\mathrm{K}$ & 26.8 & 24.7 & 791 & 0.44 & 39.8 & 30.7 & 836 & 0.43 \\
\hline $\mathrm{Ca}$ & 6.5 & 3.8 & 35.1 & 0.42 & 36.5 & 24.4 & 236 & 0.49 \\
\hline $\mathrm{Ti}$ & 0.90 & 0.67 & 10.3 & 0.31 & 0.66 & 1.64 & 61.2 & 0.28 \\
\hline V & 0.12 & 0.06 & 0.6 & 0.25 & 0.89 & 2.21 & 46.2 & 0.39 \\
\hline $\mathrm{Cr}$ & 0.20 & 0.14 & 5.46 & 0.18 & 0.14 & 0.31 & 4.69 & 0.33 \\
\hline $\mathrm{Mn}$ & 0.33 & 0.14 & 2.38 & 0.12 & 0.56 & 0.75 & 12.1 & 0.14 \\
\hline $\mathrm{Fe}$ & 9.0 & 6.6 & 81.9 & 0.10 & 4.93 & 9.18 & 147 & 0.15 \\
\hline Co & 0.14 & 0.06 & 1.03 & 0.12 & 0.16 & 0.23 & 5.53 & 0.07 \\
\hline $\mathrm{Ni}$ & 0.30 & 0.36 & 5.95 & 0.08 & 0.36 & 1.15 & 30.0 & 0.12 \\
\hline $\mathrm{Cu}$ & 0.29 & 0.08 & 1.27 & 0.11 & 0.20 & 0.42 & 13.7 & 0.12 \\
\hline $\mathrm{Zn}$ & 0.59 & 0.30 & 7.33 & 0.14 & 0.88 & 12.4 & 531 & 0.09 \\
\hline Se & 0.11 & 0.07 & 1.09 & 0.48 & 0.24 & 0.40 & 3.24 & 0.30 \\
\hline $\mathrm{Br}$ & 1.74 & 0.73 & 10.5 & 0.34 & 2.56 & 2.48 & 20.4 & 0.26 \\
\hline $\mathrm{Pb}$ & 0.43 & 0.27 & 3.37 & 0.85 & 0.61 & 1.07 & 10.8 & 0.49 \\
\hline $\mathrm{BC}$ & 309 & 150 & 2510 & 19.07 & 241 & 167 & 2147 & 20.06 \\
\hline \multicolumn{9}{|c|}{$\mathrm{PM}_{2.5}$ mass concentrations $\left(\mu \mathrm{g} \mathrm{m}^{-3}\right)$} \\
\hline $\begin{array}{l}\text { Gravitational } \\
\text { mass }\end{array}$ & 3.33 & 2.47 & 70.2 & 0.16 & 5.67 & 3.04 & 23.4 & 0.16 \\
\hline $\mathrm{RCM}$ & 2.70 & 1.71 & 43.3 & 0.029 & - & - & - & - \\
\hline RCM (\%) & 90 & 11 & 133 & - & - & - & - & - \\
\hline
\end{tabular}

grid cell counter was incremented. Where results for cluster analysis are presented, the back trajectories corresponding to the highest 20 samples in summer and winter were clustered to investigate seasonal change in source regions. For cluster formation we used the PAM (Partitioning Around Medoids; Kaufman and Rousseeuw, 2005) program.

To determine the sensitivity of the results to the starting back trajectory height, two starting heights of $300 \mathrm{~m}$ and $500 \mathrm{~m}$ agl were compared. The starting height resulted in minor differences to the back trajectory path; therefore the results from the $300 \mathrm{~m}$ agl starting height are presented. Further, these heights were chosen to reduce topographic effects and to ensure that the air masses were within the boundary layer for a significant proportion of time.

\section{Results}

\section{1. $P M_{2.5}$ chemical composition and mass closure}

A statistical summary of the species measured in the atmospheric $\mathrm{PM}_{2.5}$ samples and atmospheric mass concentrations during the sampling period are provided in Table 1 . A total of 360 days were sampled, however three outlier events were excluded from further analysis as they exceeded $2.5 \mu \mathrm{g} \mathrm{m}^{-3}$; the national 24 -h air quality standard for $\mathrm{PM}_{2.5}$. The average mass concentration of $\mathrm{PM}_{2.5}$ is $(3.3 \pm 2.5) \mu \mathrm{g} \mathrm{m}^{-3}$. This concentration is relatively low however similar to the total mass concentration at the "baseline" station at Cape Grim $(5.7 \pm 3.0) \mu \mathrm{g} \mathrm{m}{ }^{-3}$, reflecting the study site's remoteness. The dominant species of $\mathrm{PM}_{2.5}$ were $\mathrm{BC}$, sulfur, sodium and hydrogen. A comparison of the concentrations of the remaining data to those at Cape Grim (Crawford et al., 2017; Table 1), demonstrate that concentrations of the soil related elements $(\mathrm{Al}, \mathrm{Si}, \mathrm{Fe}$ ) and $\mathrm{BC}$ are higher by a factor of 3.6, 2.9, 1.8 and 1.3 , respectively, than the long term trends of regional background atmospheric PM pollution.

The $\mathrm{PM}_{2.5}$ reconstructed mass concentrations were calculated by applying the mass equations in Section 2.2.1. A comparison between the reconstructed and gravimetric $\mathrm{PM}_{2.5}$ mass concentrations, shows good agreement with a correlation coefficient of $r^{2}=0.98$ (Fig. A.1). The mean reconstructed mass yielded $90 \%$ of the measured $\mathrm{PM}_{2.5}$ mass; $\mathrm{y}$ $=0.711 \pm 0.006$ (Fig. A.1; Table 1) and is consistent with the findings of previous studies (Cohen et al., 2010). This mass deficit is attributed to the measurement process, since particle-bound water on the Teflon-membrane filter and components related to nitrates were not measured (Chow et al., 2015).

\subsection{Identified sources and source regions}

Five main factors were identified in the PMF analysis and thus five atmospheric source types were determined based on the key elemental composition in each factor. The results are summarised in Table 2. Based on airborne $\mathrm{PM}_{2.5}$ concentrations, the main sources of atmospheric emissions detected at Yarrangobilly are automobiles (45\%), secondary sulfate (21\%), smoke (12\%), windblown soil (11\%) and aged sea salt (10\%). Time series of the fingerprints are presented in Fig. 2, and Fig. 3 shows the percentage of measured elements allocated to each fingerprint. A seasonal contribution from automobiles, secondary sulfate and soil is evident but not for aged sea salt. A clear trend in smoke was observed, with higher concentrations in March, April and October. (Fig. 2).

With the largest contribution to $\mathrm{PM}_{2.5}$, the automobile factor was dominated by $\mathrm{H}$ and $\mathrm{BC}$ as well as $\mathrm{Pb}, \mathrm{S}, \mathrm{P}, \mathrm{Zn}, \mathrm{Cu}, \mathrm{V}$ and $\mathrm{Cr}$ (factor 1 : Table 2; Fig. 3). The automobile aerosol time series is strongly seasonal, peaking in austral summer (Fig. 2a). Back trajectory cluster analyses

Table 2

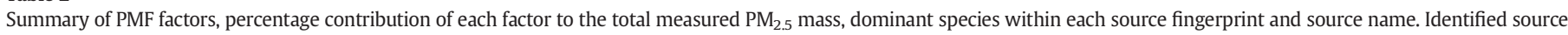
profiles are summarised in Fig. A.2.

\begin{tabular}{|c|c|c|c|}
\hline Factor & $\begin{array}{l}\text { \% Mass } \\
\text { contribution } \\
\pm \\
\text { error }\end{array}$ & Dominant species & Source; comments \\
\hline $\begin{array}{c}\text { Factor } \\
1\end{array}$ & $44.9 \pm 0.83$ & $\begin{array}{l}\mathrm{H}, \mathrm{N}, \mathrm{BC}, \mathrm{P}, \mathrm{Cu}, \mathrm{Cr}, \mathrm{Pb}, \mathrm{Br}, \mathrm{Zn}, \\
\mathrm{V}, \mathrm{Mn}, \mathrm{Co} \text { and } \mathrm{S}\end{array}$ & $\begin{array}{l}\text { Automobile; This factor is composed mainly of } \mathrm{H} \text {, a dominant } \mathrm{BC} \text { component; indicative of vehicular emissions (Zhu } \\
\text { et al., 2002; Fujita et al., 2007), and the elements: Pb from resuspension of historic leaded petrol (Kristensen, 2015), S } \\
\text { and P from diesel engine oil, } \mathrm{Br} \text { and } \mathrm{Mn} \text { from fuel additives, } \mathrm{Cu} \text { and } \mathrm{Cr} \text { from clutch and brake lining wear, Zn from tyre } \\
\text { wear and V in lubricating oils. }\end{array}$ \\
\hline $\begin{array}{l}\text { Factor } \\
2\end{array}$ & $21.4 \pm 0.87$ & $\begin{array}{l}\mathrm{S}, \mathrm{Ni}, \mathrm{P}, \mathrm{Na}, \mathrm{Cr}, \mathrm{V}, \mathrm{Co}, \mathrm{N}, \mathrm{Cu}, \mathrm{Pb} \\
\text { and } \mathrm{Zn}\end{array}$ & $\begin{array}{l}\text { Secondary Sulfate; } \mathrm{SO}_{2} \text { from the combustion of fossil fuels, e.g. coal-fired power stations. Most of the sulfate on the } \\
\text { filters were fully neutralised and occurred as }\left(\mathrm{NH}_{4}\right)_{2} \mathrm{SO}_{4} \text {, not as ammonium bisulfate }\left(\mathrm{NH}_{4}\right) \mathrm{HSO}_{4} \text { or sulfuric acid } \mathrm{H}_{2} \mathrm{SO}_{4} \text {. } \\
\text { Also contains tracers from industrial heavy metals. }\end{array}$ \\
\hline $\begin{array}{l}\text { Factor } \\
3\end{array}$ & $12.3 \pm 0.58$ & $\mathrm{~K}, \mathrm{Zn}, \mathrm{Se}, \mathrm{Br}, \mathrm{BC}$ & $\begin{array}{l}\text { Smoke; The main contributor to this factor is K; a tracer for biomass burning, produced by bushfires and hazard } \\
\text { reduction burns (Cachier et al., 1991; Chow et al., 2015). It also includes the contribution of plant and/or soil elements } \\
\text { (Zn, Se). }\end{array}$ \\
\hline $\begin{array}{c}\text { Factor } \\
4\end{array}$ & $11.25 \pm 0.45$ & $\mathrm{Al}, \mathrm{Fe}, \mathrm{Ti}, \mathrm{Si}, \mathrm{Ca}, \mathrm{Mn}, \mathrm{Ni}$ and $\mathrm{Na}$ & $\begin{array}{l}\text { Soil; contains the five main elements associated with soil dust, in addition to } \mathrm{Mn}, \mathrm{Ni} \text { and } \mathrm{Na} \text {. The }[\mathrm{Al} / \mathrm{Si}] \text { ratio is } 0.37 \text {, } \\
\text { slightly above the range for alumina-silicates }(0.25-0.35 \text {; Cohen et al., 2010). }\end{array}$ \\
\hline $\begin{array}{l}\text { Factor } \\
5\end{array}$ & $10.14 \pm 0.38$ & $\mathrm{Cl}, \mathrm{Na}, \mathrm{Ca}$ & $\begin{array}{l}\text { Sea Aged; }[\mathrm{Na} / \mathrm{Cl}] \text { ratio is } 1.13 \text {, higher than seawater (0.86), suggesting a loss of } \mathrm{Cl} \text { during transport from sea to } \\
\text { continent (Möller, 1990). }\end{array}$ \\
\hline
\end{tabular}




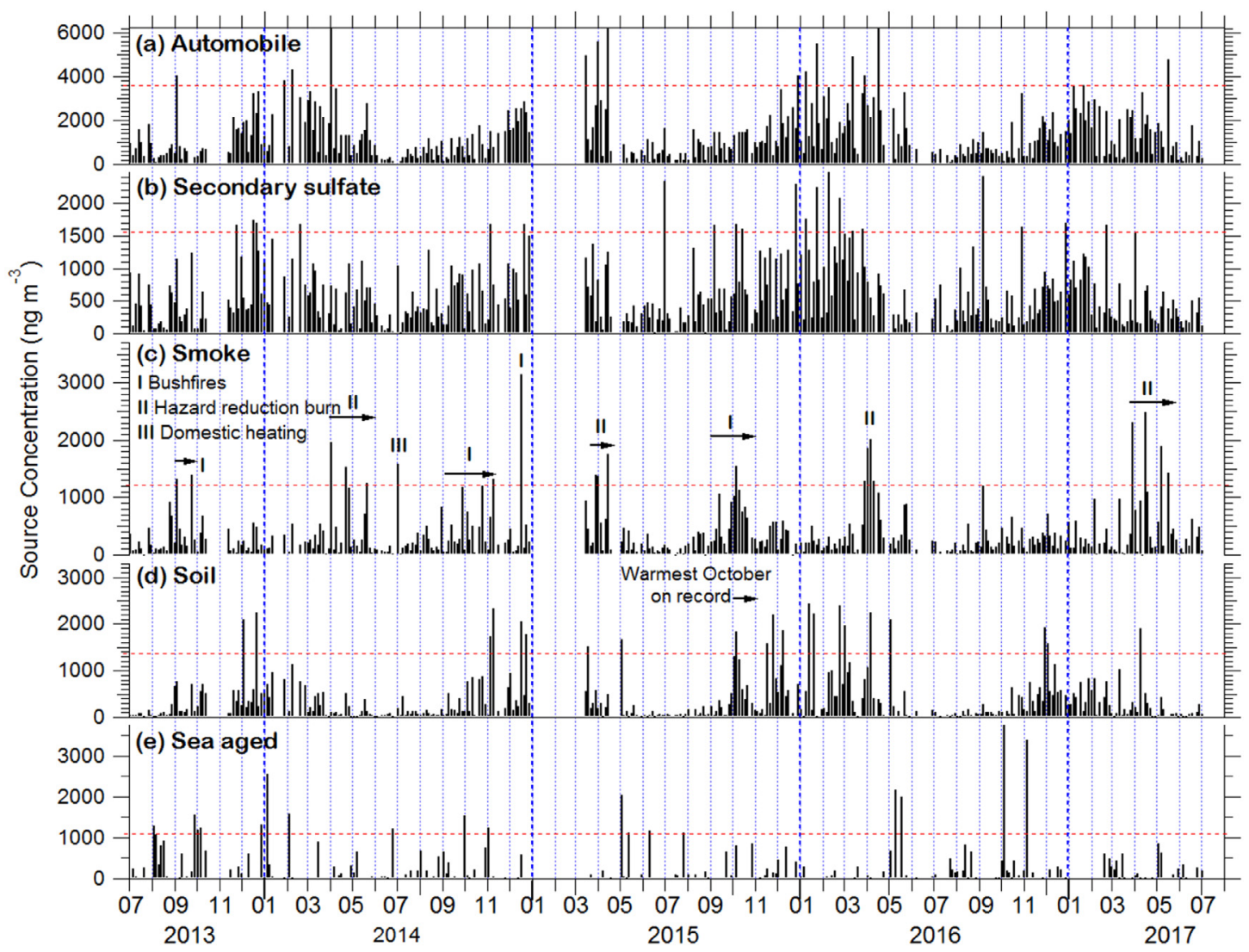

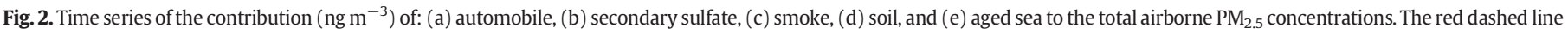
in each source indicates the threshold (mean $+2 \sigma)$ for outlier events. The 2.5 month gap between January and mid-March 2015 indicates no available data.

identified the higher proportion of automobile aerosols in summer compared to winter and this is attributed to increased visitor numbers in this tourist area and different directions of the fetch region (Fig. 4a).

Secondary sulfate was the second largest contributor to $\mathrm{PM}_{2.5}$ (21\%; factor 2: Table 2) with maximum concentrations in summer (Fig. 2b). The back trajectory density map for the top 23 secondary sulfate measurements show some of the back trajectories have passed over New South Wales and Victorian urban regions (Fig. 4b). Furthermore, two of the three trajectory clusters for summer and winter had passed over power stations located in NSW and Victoria (Fig. 4b) indicating the dominance of secondary sulfate from coal derived pollution. However, one trajectory cluster in summer and winter is localised and considering a number of trace elements were present in the secondary sulfate fingerprint (Fig. 3; Table 2), this indicates a smaller contribution of secondary sulfate from local industrial release (discussed further in Section 4.1).

Smoke (factor 3: Table 2) contributes $12 \%$ to the $\mathrm{PM}_{2.5}$ mass. Potassium is the major component of the smoke factor, $59 \%$ of the $\mathrm{K}$ was allocated to this factor, with significant allocations from Zn (35.4\%), Se (27\%), $\mathrm{Br}(25 \%)$ and BC (20\%; Fig. 3). Outlier events in the smoke time series (Fig. 2c) correspond to significant increases in regional fire emissions

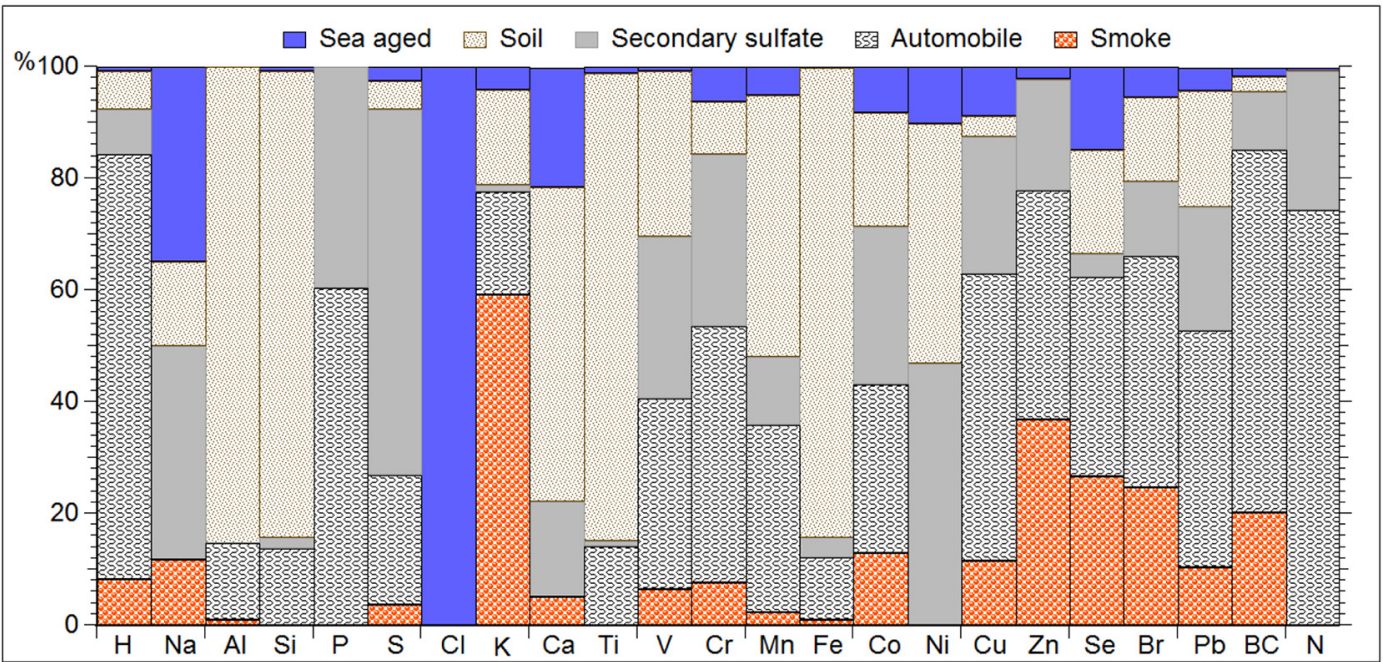

Fig. 3. Percentage allocation of each element's mass to a source. 
from bushfires, controlled hazard reduction burns and domestic wood stove heating (labelled I-III respectively) and brought to site from northern air masses (Fig. 4c), which we examine in further detail.

The highest concentration of smoke occurred on the 17 December 2014. Several fires were ignited by lightning on 15 December 2014 in central and north-eastern Victoria, inland of the Great Dividing Range (BoM, 2017a). The four most significant fires were large scale (120 ha to $6800 \mathrm{ha}$ ), between 154 and $286 \mathrm{~km}$ southwest of the study site. The close proximity of these fires and intensity of the smoke signal recorded at the study site, suggests the likely impact of these fires.

Spring (SON) 2013, 2014 and 2015 were Australia's three warmest springs on record (BoM, 2017b) characterised by above average temperatures and coincided with below average winter-spring rainfall. These conditions reduced soil (and vegetation) moisture which promoted significant bushfires in New South Wales, south Queensland and Victoria, respectively. Elevated concentrations of smoke were recorded for these periods (Fig. 2c), suggesting Jillabenan Caves was influenced by smoke from these events.

Based on fire incident data obtained from the National Parks local fire service, local hazard reduction burns correlated with the observed elevated concentrations of smoke in May 2014, April 2015 and 2016 and March to May 2017. Elevated smoke levels were also recorded for April 2014 and March 2015 and are likely to be due to hazard reduction burns further afield in NSW and Victoria; as autumn (MAM) is the prime hazard reduction period for NSW and Victoria. The winter July 2014 outlier event is attributed to wood fire smoke from domestic heating in the local vicinity; due to the passage of an unusual vigorous cold front producing snow as low as $600 \mathrm{~m}$ across the NSW tablelands (BoM, 2017a). Overall, higher concentration trends in March and April are due to hazard reduction burns, whereas higher concentrations in spring are attributed to bushfires.

Soil dust (11\%; factor 4: Table 2) contains the five key crustal elements $\mathrm{Al}, \mathrm{Si}, \mathrm{Ca}$, Ti and Fe, as well as $\mathrm{Na}$ and $\mathrm{Ni}$ (Table 2; Fig. 3). The density map of outlier events shows that the higher cell crossings of the soil factor are associated with winds mainly from the north-west quadrant (Fig. 4d). Similar to Cohen et al. (2011) long-range dust transport from 21 outlier events to the study site from 14 desert regions and the Riverina area were investigated (Fig. 5). As indicated by the dots in Fig. 5, the main dust source regions with the highest intersections were the Riverina (box 15) and Lake Mungo (box 1) in the Murray Darling Basin and Lake Windaunka (box 2), East Flinders ranges (box 3 ) and Olympic Dam (box 4) within the Lake Eyre Basin. Soil is picked up from
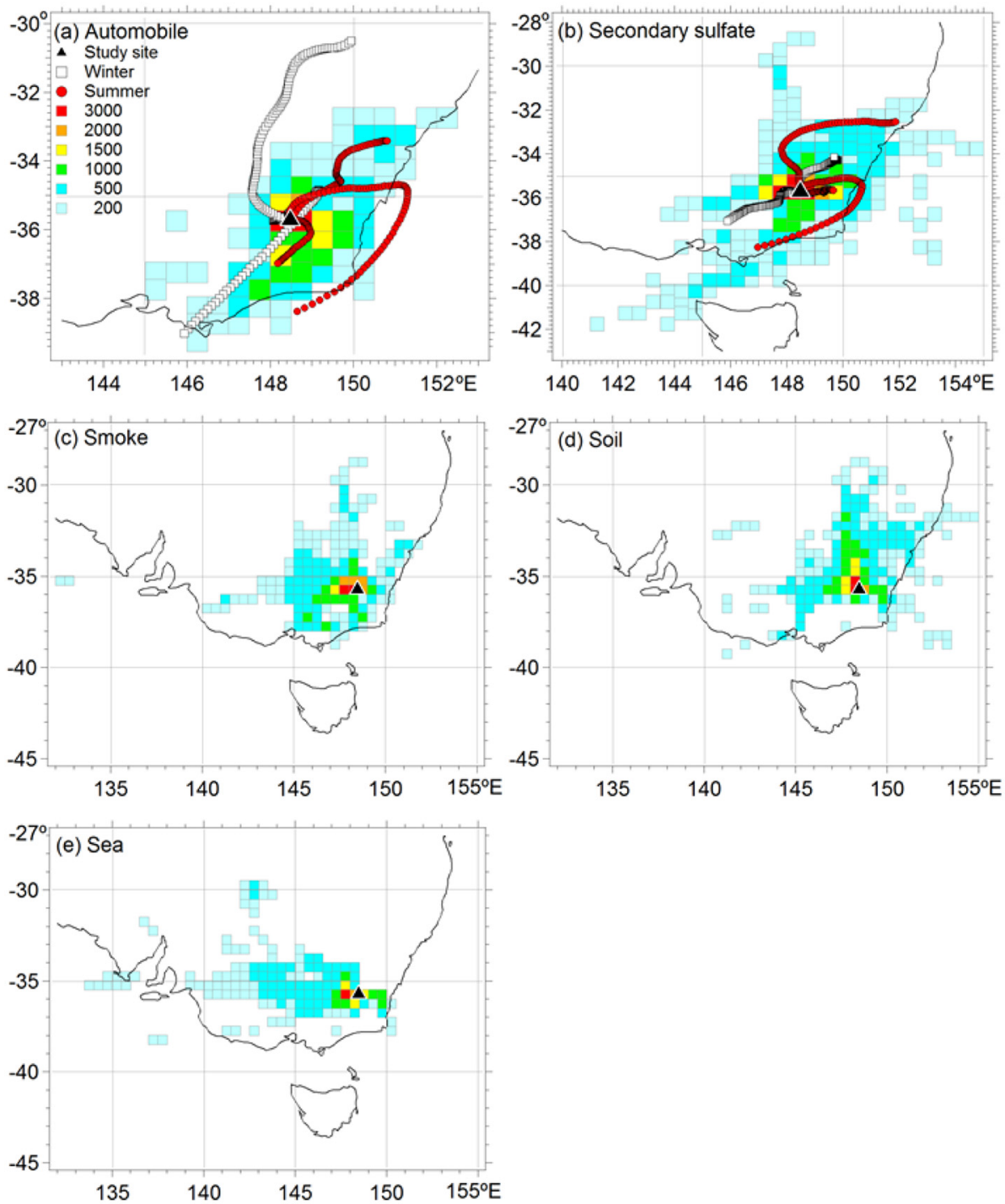

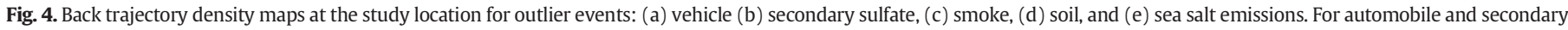

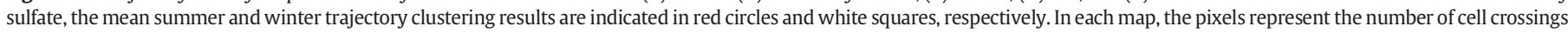
by back trajectories and the study site location is denoted as a solid triangle. The marginal graphics of each image show the latitude and longitude. 


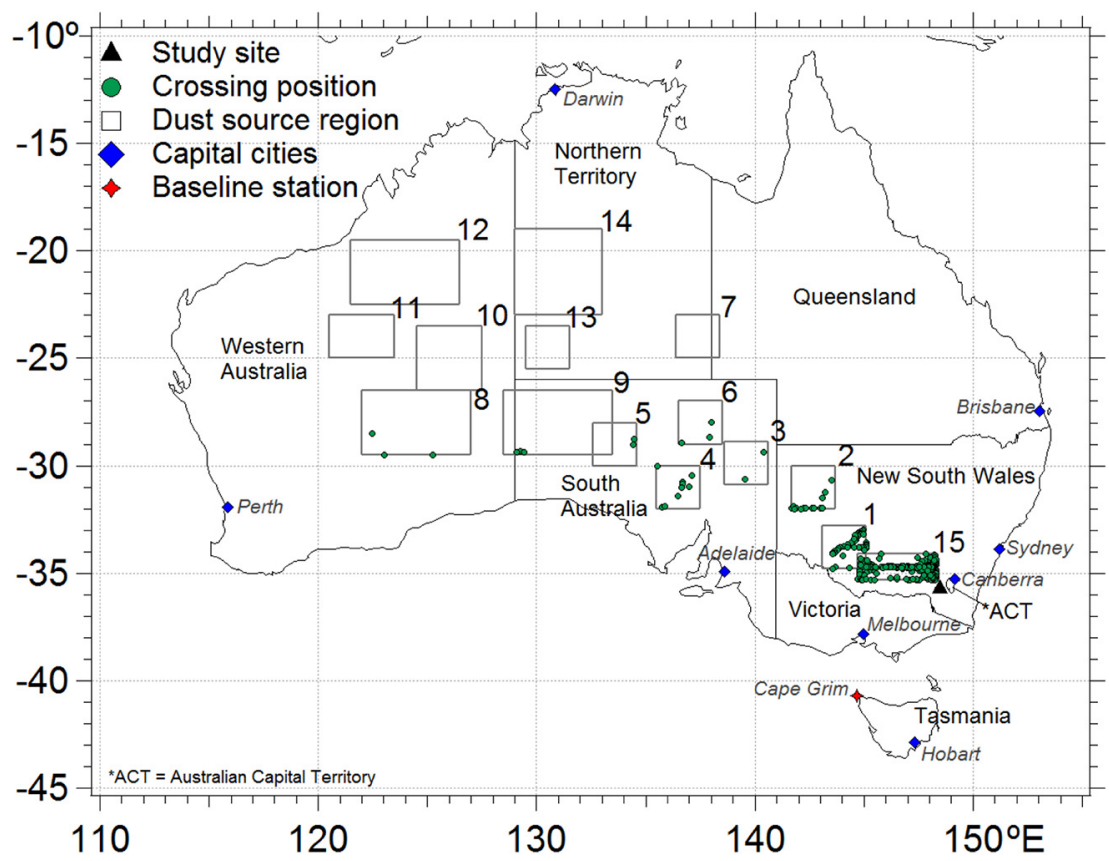

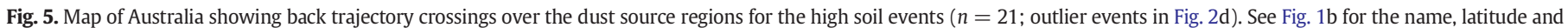
longitude of each rectangular dust source region.

these regions and crosses over the Riverina before arriving at our site. This region is one of the major sources of Australian dust and the location of dry terrestrial salt lakes (Prospero et al., 2002). The observed $\mathrm{Na}$ in soil dust is attributed to terrestrial salt input from this source region. The time series (Fig. 2d) shows a seasonal cycle with a latespring to summer maximum, however there was a particularly high concentration of soil-derived particles recorded in October 2015, coinciding with Australia's warmest October on record, which was driven by a strong El Niño in the Pacific. Across the entire southern half of Australia, including the SE and arid interior of Australia, strong wind conditions, above average temperatures and dry conditions; belowaverage rainfall and soil moisture, were recorded (BoM, 2017c). The presence of $\mathrm{Mn}$ and $\mathrm{Ni}$ is attributed to entrainment from local industry and agricultural regions in the Riverina, respectively, evidenced by back trajectory air mass passage over these locations.

Aged sea salt (factor 5; Table 2) has the lowest contribution to the $\mathrm{PM}_{2.5}$ mass at $10 \%$, this is expected due to the remote inland location. This is in contrast to the dominate source contribution of 57\% at Cape Grim, due to the coastal location. Time series of the aged sea salt source is variable with no obvious seasonal trend (Fig. 2e). The density map of outlier events shows a dominant westerly component (Fig. 4e) consistent with the mean westerly wind direction for the study site (Fig. 1c). Moreover, for these outlier events the back trajectory density map shows that winds originating from the Southern Ocean had passed over inland saline regions of Lake Eyre before arriving at our site (Fig. 4e). Although the sea salt source is predominantly comprised of $\mathrm{Cl}$, with $100 \%$ allocated to this source, $22 \%$ of the $\mathrm{Ca}$ and $33 \%$ of the $\mathrm{Na}$ was also allocated to this source. Moreover $15 \%$ of the Na originates from soil (Fig. 3), and as identified in the soil source, while over land, $\mathrm{Ca}$ and $\mathrm{Na}$ from inland salt lakes are incorporated in the air mass.

\section{Discussion}

\subsection{Aerosol sources}

By applying the PMF model with the aerosol elemental data set as input, five main atmospheric sources were identified at Yarrangobilly: traffic emissions from automobiles, secondary sulfate from coal combustion, smoke from biomass burning, mineral dust from windblown soil and aged sea salt. The distinctive chemical characteristics of each source profile were evaluated and the percentage of each element allocated to the different sources was estimated. Seasonality in the sources was identified; a higher contribution of secondary sulfates and automobile emissions in summer, and dust and smoke aerosols in spring dominated. Moreover, in addition to local contributions, long-range contributions from distant sources were also determined by examining extreme events using back trajectories.

The predominant source of $\mathrm{PM}_{2.5}$ is traffic-generated emissions (45\%; Table 2). Based on a quantitative meta-analysis of published literature, Zhou and Levy, 2007 concluded maximum concentrations of fine and ultrafine particles from automobile emissions are observed between 100 and $400 \mathrm{~m}$ from the roadway. As our aerosol monitoring sampler is between 30 and $500 \mathrm{~m}$ from the local road network (Fig. 1a), the observed vehicle emissions are attributed to contributions from these access roads. The Yarrangobilly Caves entry and exit roads along the Snowy Mountains Highway are situated $2300 \mathrm{~m}$ and at an elevation of $1287 \mathrm{~m}$ a.s.l. from the aerosol unit and the impact from vehicle emissions from the highway are considered to be limited. The highest contributions of automobile emissions occurred in summer (Fig. 2a), consistent with seasonal summer and winter visitor volume data (2013-2017); where more vehicles access the tourist caves in summer than in winter. The Snowy Mountains Highway and access roads to the caves are located north-east and south-east to the sampling site (Fig. 1a). Based on trajectory clustering results (Fig. 4a); in summer, easterly winds dominate, which pick up vehicle emissions from the road network and transport them toward the sampling site, whereas the wind direction changes to a more westerly component in winter which may also contribute to the drop in vehicle emissions due to the lower density of roads from this direction.

Accounting for $21 \%$, secondary sulfates is the second largest contributor of the total $\mathrm{PM}_{2.5}$. The two main sources of secondary aerosols are ascribed to coal combustion burning and local industry. During the period of this study, five coal fired power stations were operational in New South Wales: Vales Point and Eraring situated on the southern shores of Lake Macquarie, Bayswater and Liddell located in the Upper Hunter region of NSW and Mt. Piper located near Lithgow in the Central West of New South Wales. In the state of Victoria, four coal fired power stations: Loy Yang A, Loy Yang B, Yallourn and Hazelwood power stations located in the Latrobe Valley of Victoria, were also operational. 
The back trajectory density map for secondary sulfate measurements show that some of the back trajectories had passed over the coal-fired power plants in New South Wales and some (but a lower number) over the coal-fired power plants in Victoria (Fig. 4b).

Furthermore, results obtained from the trajectory clustering also show air masses bringing secondary sulfate from the coal-fired power plants in NSW and Victoria in both summer (Fig. 4b; red circles) and winter (Fig. 4b; white squares). This confirms secondary sulfate is primarily coal-derived pollution; however a number of trace elements were associated with the secondary sulfate fingerprint (Fig. 3; Table 2). Coal burning does produce a number of trace metals (e.g. Mn, P, Ti, Zn, etc.; Nalbandian, 2012), yet observations from the trajectory clusters are consistent with local industry contributing secondary sulfate, and metal emissions. Based on a database search of the National Pollution Inventory (NPI, 2017), Hanson Construction Materials at Williamsdale, located at about $65 \mathrm{~km}$ to the north east of the site and Tumbarumba Structural Softwood Sawmill, located $48 \mathrm{~km}$ south west of the site would have contributed to the $\mathrm{SO}_{2}$ and metal emissions (e.g. $\mathrm{Pb}, \mathrm{Ni}, \mathrm{Zn}$ ). Secondary aerosol contributions varied significantly seasonally and maximum concentrations were observed in summer (Fig. 2b). This seasonality is supported by the fact that in summer, the combination of pollutants and high levels of ultraviolet (UV) light cause strong photochemical reactions. For example, ammonium sulfate $\left(\left(\mathrm{NH}_{4}\right)_{2} \mathrm{SO}_{4}\right)$ aerosol is formed when gaseous sulfur dioxide $\left(\mathrm{SO}_{2}\right)$ is oxidised to sulfuric acid $\left(\mathrm{H}_{2} \mathrm{SO}_{4}\right)$ by UV light and then neutralised by ammonia $\left(\mathrm{NH}_{3}\right)$ in the atmosphere (Arrowsmith and Hedley, 1975).

Smoke emissions contributed $12 \%$ to the total $\mathrm{PM}_{2.5}$ mass (Table 2). Compared to the reported results from the remote site at Cape Grim, this source contribution is similar in magnitude; where smoke accounts for $13 \%$ of the total $\mathrm{PM}_{2.5}$ (Crawford et al., 2017). At Yarrangobilly, smoke has higher contributions in autumn and October (Fig. 2c), consistent with local emission sources from hazard reduction burns and bushfires, respectively. The back trajectory density map for smoke (Fig. 4c) showed elevated concentrations of smoke were also attributed to longrange transport from intense bushfire events in NSW, south Queensland and Victoria. This was similar to the observations of Crawford et al., 2017, which showed smoke transported to Cape Grim originated from both local and long-range contribution from the Australian mainland. Due to the remote inland location in a temperate forest, these results are in accord with expectations for the mid-latitudes, since most of the Australian biomass burning emissions are from the savannah regions of tropical Australia (Kasischke and Penner, 2004).

The Snowy Mountains in south-eastern Australia receives terrestrial soil-derived aerosols in spring from long-range transport from the Murray Darling Basin and Lake Eyre (Section 3.2). This is supported by back trajectory analysis of outlier days that showed that air masses travelled over salt sources in the region before delivery to site (Fig. 5). The contribution of $\mathrm{Na}$ to the source fingerprint (Table 2; Fig. 3) provided further evidence that terrestrial $\mathrm{Na}$ from the zone of salt lakes in the north-west is co-transported with terrestrial soil from this region. The input of terrestrial salt from this source region has also been detected at other remote inland areas, for example Wagga Wagga situated $118 \mathrm{~km}$ NW of our study site and Cobar (Shiga et al., 2011). In addition, local emissions of metals e.g. Ni and Mn can be entrained and then adhered to aerosols as the air masses pass over agriculture and industrial regions, as has been inferred in previous studies (Marx et al., 2008).

Australia is the dominant source of dust in the Southern Hemisphere with substantial dust mobilised from Lake Eyre and the Great Artesian Basin starting in spring and reaching a maximum in the austral summer (Prospero et al., 2002; Mitchell et al., 2010; Shao et al., 2011). The high soil events were evident in the four-year time series as a late spring to summer maximum, the impact of which generated a strong depositional signal during the 2015-16 El Niño that caused drought conditions (Fig. 2d). This seasonality is consistent with maximum dust activity documented from the region. There is clear evidence that drought conditions can alter the landscape and precipitate the transition to an erosional regime; enhancing the production and mobilisation of large quantities of dust from desert surfaces (Prospero and Lamb, 2003), because of this synergy, the increased dust measurements during the 2015-16 El Niño indicates the region is sensitive temporally and spatially to the impact of a changing climate.

The contribution of sea salt aerosols (10\%) is comparable to other natural aerosols in the Snowy Mountains. The results indicated marine aerosols traversed a significant distance from the Southern Ocean to the high altitude interior part of south-eastern Australia (Fig. 4e). The source of $\mathrm{Cl}$ is sea salt aerosols (Fig. 3) and chloride depletion during inland transport was identified (Table 2). The process of chloride depletion is a common atmospheric reaction of far-travelled marine aerosols, where $\mathrm{Cl}$ in the sea salt aerosols reacts with an anthropogenic source of nitric and sulfuric acid, forming gaseous $\mathrm{HCl}$ (Ten Harkel, 1997). Considering the study site has high concentrations of $\mathrm{N}$ and $\mathrm{S}$ mainly from anthropogenic sources, when sea-salt aerosols are transported to site, chloride depletion reactions explain the removal of $\mathrm{Cl}$ in the atmosphere.

\subsection{Overall implications}

Other than the work of Suni et al., 2008 and Paton-Walsh et al., 2014, there is: sparsity of data on atmospheric emissions deposited in an Australian alpine forest, and no previous high-resolution data from the Snowy Mountains. To fill this gap in current knowledge, the average percentage $\mathrm{PM}_{2.5}$ load to the atmosphere and the average elemental composition in the remote high alpine air over a four-year timeframe are quantified for the first time. Such results may be informative in evaluating the extent to which atmospheric aerosols are impacting the natural regional climate (Rosenfeld, 2000; Nicholls, 2005) and subsequent impacts on the distribution and diversity of species in these alpine environments (Green and Pickering, 2002; Pickering et al., 2008; Slatyer, 2010).

Automobile and secondary sulfate emissions represent $70 \%$ of the atmospheric loading and therefore the primary mode of metal contamination from the atmosphere. A study from the Snowy Mountains demonstrated that the region's peat bogs have accumulated substantial quantities of anthropogenic metals since industrialisation, approximately 150 years ago (Marx et al., 2010).The sources were ascribed to mining and smelting, coal combustion and agriculture. The monitoring data from this study quantifies the anthropogenic $\mathrm{PM}_{2.5}$ source from the Snowy Mountains, and are in agreement with the postulated findings of Marx et al., 2010.

This study has demonstrated that long range transport of anthropogenic trace metal pollutants can be transported to remote regions as far as south-eastern Australia, and has also been demonstrated to be transported to Cape Grim, Tasmania (Crawford et al., 2017) and as far as New Zealand (Hesse, 1994; Marx et al., 2008). Furthermore, this study provides evidence that long range transport of loess and salt from the interior to the alpine zone of south-eastern Australia is deposited annually during the Austral autumn-summer, with increased amounts during the drought and El Niño periods. The soil properties of the alpine environment in south-eastern Australia are known to be influenced by aeolian dust deposits (Costin, 1954; Chen et al., 2002) although at a lower rate compared to earlier times. For example, during glacial times the rates of dust deposition was concluded to be 1.5 to 3 times those at present (Hesse, 1994), while the current rates of dust deposition are estimated to be $1-7 \mathrm{~mm}$ per thousand years on the basis of dust extracted from drift wood in the Snow Mountains (Walker and Costin, 1971). Aeolian dust have high clay content (Butler, 1956), hence dust accession may modify the soil profile by imparting properties different to the underlying parent material.

\subsection{Implications for palaeo studies}

From a palaeo context, the potential importance of natural aerosol deposition in a pre-automobile and pre-industrial period is apparent. 
Based on measurements presented here, the Snowy Mountains receives fine particles of soil and smoke that are transported by aeolian processes from distant regions and to high altitudes. Similar to Mitchell et al., 2010 we identified that during a dry El Niño event a significant increase in aerosol loading within the dust season from Lake Eyre was observed. Additionally enhanced smoke concentrations from bushfire activity driven by increased spring temperatures was also observed (Section 3.2) and demonstrated to be transported long distances to regions as far as south-eastern Australia. In this regard, trace elements derived from wind-blown soil and smoke aerosols could serve as proxy data to reconstruct past episodes of aridity in sedimentary records.

Bushfires yield smoke emissions of K, Zn, Se, Br and BC (Fig. 3) and these aerosol particles are water-soluble (Yamasoe et al., 2000). Fine windblown soil is composed mainly of $\mathrm{Al}, \mathrm{Si}, \mathrm{Ca}$, Ti and $\mathrm{Fe}$, as well as $\mathrm{Mn}, \mathrm{Ni}$ and $\mathrm{Na}$ (Fig. 3 ) and are derived from a mixture of minerals of varying solubilities e.g. aluminosilicate clays, metal oxides, carbonates, gypsum and halite salts (Costin et al., 1952; Costin, 1955). However heterogeneous reactions of soil dust particles with reactive gasses including nitric, hydrochloric, and sulfuric acids can increase their hygroscopicity through the conversion to more soluble compounds (Sullivan et al., 2009). The deposited water soluble trace element fraction of the smoke and soil dust in the soil zone are therefore labile and available for biological uptake, can undergo chemical processes in the soil zone, or transported by percolating rainwater through the subsoil and bedrock to cave systems, or discharged to lakes, reservoirs and river systems. The notion that dust and smoke can influence the physical and geochemical properties of soils and sediments is important as it may complicate interpretation in proxy records particularly if aerosol deposition is the dominant source of trace element input rather than the local bedrock (Chadwick et al., 1999), or when there is an increased rate of aeolian deposition due to an increased frequency of events. This is particularly relevant in regions like the Snowy Mountains where changes in the climate are forecasted to decrease precipitation and increase the frequency of fires (Nicholls, 2005).

Constraining atmospheric aerosol sources provides a unique opportunity to accurately shape our understanding of climate and environmental conditions controlling aerosol inputs to soil and water bodies, enabling accurate palaeo-environmental interpretations to be made from trace elements preserved in natural archives regionally. Analysis of aerosols highlights that there are a range of potential processes that may affect the palaeo-environmental interpretation of trace elements in sedimentary archives such as lake sediments, peat deposits and speleothems. An understanding of the subsequent processes and mechanism(s) leading to the delivery and preservation of trace elements to the sedimentary archive in the palaeo record is also required. In the case of speleothem archives we will be addressing this in a forthcoming paper, where the atmospheric dataset from this study is applied via a mass balance, to quantify the contribution of aerosols to a cave drip water dataset that was collected concurrently at the same site.

\section{Conclusions}

This paper presents the first long term data set at Yarrangobilly in the Snowy Mountains, SE Australia, providing a detailed quantitative analysis of $\mathrm{PM}_{2.5}$ during the four-year monitoring period. This includes: a statistical summary of mean $\mathrm{PM}_{2.5}$ mass concentrations for aerosol species, temporal variations and elemental percentage allocation to each measured source. Five sources, representing: automobile, secondary sulfate, smoke, soil and aged sea salt, describe the contributors to fine particles in the alpine air of the Snowy Mountains region.

Distinctive seasonality occurred for the different sources. We identified automobile emissions increased over summer due to the increase in visitors, where access points around the remote site is by vehicles. The secondary sulfate maxima during summer is caused by photochemical reactions and increased smoke emissions in autumn and spring is attributed to the season for hazard reduction burns and bushfires. Seasonality of dust entrainment in Australia during late (austral) spring to summer caused maximum soil emissions at the study site. No trends were observed for aged sea salt.

It was concluded that long-distance $\mathrm{PM}_{2.5}$ transport was an important mechanism for particle transport from point sources to the remote high alpine site. Specifically, the second major source of $\mathrm{PM}_{2.5}$, secondary aerosols from coal combustion was transported from regional NSW and Victorian power stations. Also, smoke from bushfires originating in the major cities was transported to site. Prevailing westerly air currents carried aeolian $\mathrm{Na}$ and soil from the inland saline regions of Lake Eyre and Murray Darling basins and aged sea salt from the Southern Ocean to the south-east. Furthermore, due to the long transport time over land, we identified chloride depletion in sea salt aerosols. In addition, we identified that trace metals are entrained by the wind and transported to the study site, as evidenced by metal enrichment of the secondary sulfate and soil factor through the passage over local industry as well as the agricultural region in the Riverina.

Moreover, we identified that the current climate in particular drought and El Niño periods increase the smoke and soil aerosol loading, suggesting they may serve as proxies for palaeo-studies. We also postulated that the introduction of water-soluble salts and aeolian clay to the local soil may gradually alter the soil physical and geochemical profile. Hence an understanding of fine particle measurements and soil processes is required for accurate palaeo-environmental interpretations in natural archives.

\section{Acknowledgements}

The authors gratefully acknowledge the support of the staff at the Centre for Accelerator Science, ANSTO for access to the ion beam analysis facilities. The NOAA Air Resources Laboratory (ARL) made available the HYSPLIT transport and dispersion model and the relevant input files for generation of back trajectories used in this paper. George Bradford and the staff at Yarrangobilly Caves and NSW NPWS are thanked for their dedication and on-going field support and access permission. We also thank NPWS Southern Ranges senior fire ranger Andrew Grant for providing fire and controlled burn data. We thank Jianmen Chen and two anonymous reviewers for their constructive reviews that improved the manuscript.

\section{Appendix A. Appendices}

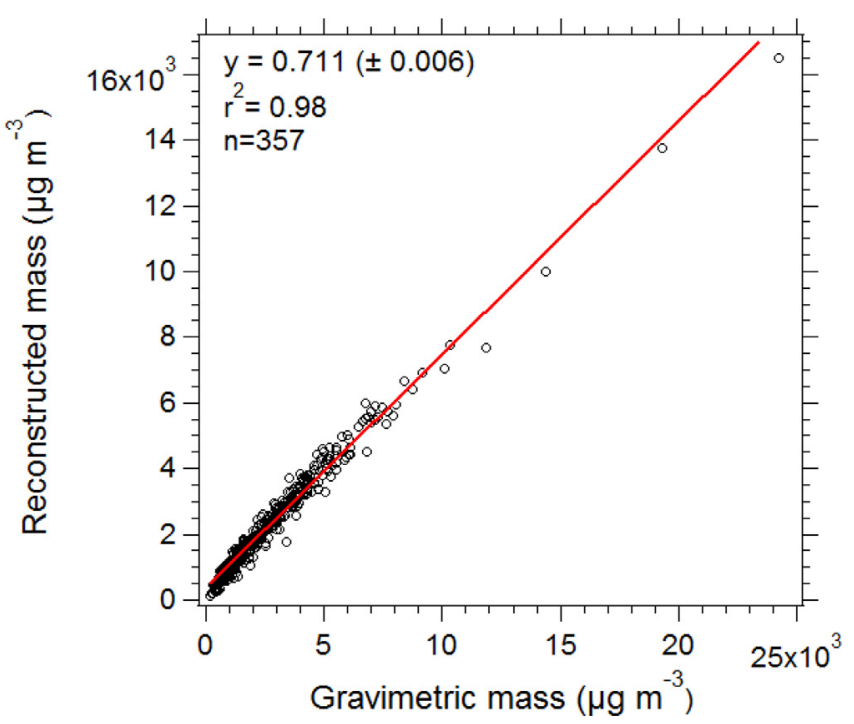

Fig. A.1. Linear regression analysis between reconstructed vs. gravimetric mass for 357 samples collected at Jillabenan Cave, NSW, Australia, between 2013 and 2017. 

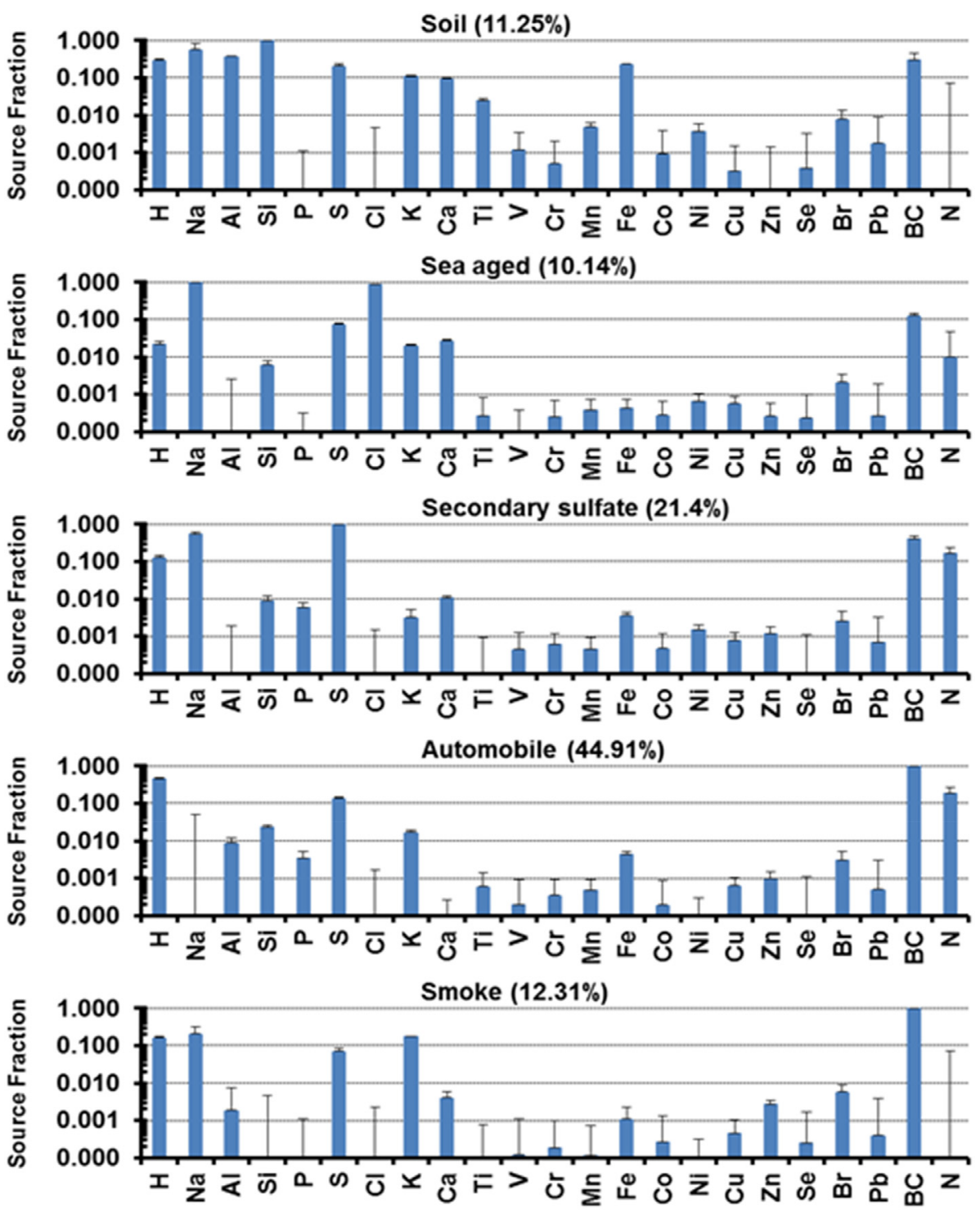

Fig. A.2. Source profiles for the identified sources from the PMF model.

\section{References}

Allan, M., Fagel, N., Van Rampelbergh, M., Baldini, J., Riotte, J., Cheng, H., Edwards, R.L. Gillikin, D. Quinif, Y. Verheyden, S, 2015. Lead concentrations and isotope ratios in speleothems as proxies for atmospheric metal pollution since the industrial revolution. Chem. Geol. 401, 140-150.

Arrowsmith, A., Hedley, A.B., 1975. The formation of ammonium sulphate particles by atmospheric reactions. Rev. Pert. Quim 17, 26.

Bird, J.R., 1990. Total analysis by IBA. Nucl. Instrum. Methods Phys. Res., Sect. B 45 (1-4), 514-518.

Bird, J.R., Williams, J.S., 1989. Ion Beams for Material Analysis. Academic Press, p. 719

BoM, 2017a. http://www.bom.gov.au/climate/mwr/ (last access: 30 November 2017).

BoM, 2017b. http://www.bom.gov.au/climate/current/annual/aus/ (last access: 30 November 2017)

BoM, 2017c. http://www.bom.gov.au/climate/current/statements/scs52.pdf (last access: 30 November 2017).

Butler, B.E., 1956. Parna-an aeolian clay. Aust. J. Sci. 18 (5), 145-151.

Cachier, H., Ducret, J., Bremond, M.P., Yoboue, V., Lacaux, J.P., Gaudichet, A., Baudet, J., 1991. Biomass burning aerosols in a savanna region of the Ivory Coast. In: Levine, J. (Ed.), Global Biomass Burning: Atmospheric, Climatic and Biospheric Implications. MIT Press, Cambridge, MA, pp. 174-180.

Chadwick, O.A., Derry, L.A., Vitousek, P.M., Huebert, B.J., Hedin, L.O., 1999. Changing sources of nutrients during four million years of ecosystem development. Nature 397 (6719), 491-497.

Chen, X.Y., Spooner, N.A., Olley, J.M., Questiaux, D.G., 2002. Addition of aeolian dusts to soils in southeastern Australia: red silty clay trapped in dunes bordering Murrumbidgee River in the Wagga Wagga region. Catena 47 (1):1-27. https://doi.org/ 10.1016/S0341-8162(01)00176-X
Chow, J.C., Lowenthal, D.H., Chen, LW.A., A, L-W., Wang X., Watson, J.G., 2015. Mass reconstruction methods for $\mathrm{PM}_{2.5}$ : a review. Air Qual. Atmos. Health 8 (3), 243-263.

Cohen, D.D., 1998. Characterisation of atmospheric fine particles using IBA techniques. Nucl. Instrum. Methods Phys. Res., Sect. B 136:14-22. https://doi.org/10.1016 S0168-583X(97)00658-7.

Cohen, D.D., Bailey, G.M., Kondepudi, R., 1996. Elemental analysis by PIXE and other IBA techniques and their application to source fingerprinting of atmospheric fine particle pollution. Nucl. Instrum. Methods Phys. Res., Sect. B 109, 218-226.

Cohen, D.D., Stelcer, E., Hawas, O., Garton, D., 2004a. IBA methods for characterisation of fine particulate atmospheric pollution: a local, regional and global research problem. Nucl. Instrum. Methods Phys. Res., Sect. B 219, 145-152.

Cohen, D.D., Garton, D., Stelcer, E., Hawas, O., 2004b. Accelerator based studies of atmospheric pollution processes. Radiat. Phys. Chem. 71 (3-4), 759-767.

Cohen, D.D., Crawford, J., Stelcer, E., Bac, V.T., 2010. Characterization and source apportionment of fine particulate sources at Hanoi from 2001 to 2008. Atmos. Environ. 44 (3), 320-328.

Cohen, D.D., Stelcer, E., Garton, D., Crawford, J., 2011. Fine particle characterization, source apportionment and long-range dust transport into the Sydney Basin: a long term study between 1998 and 2009. Atmos. Pollut. Res. 2 (2), 182-189.

Colbeck, I., Lazaridis, M., 2014. Aerosol Science: Technology and Application. John Wiley \& Sons Ltd., West Sussex, UK, p. 496.

Costin, A.B., 1954. A Study of the Ecosystems of the Monaro Region of NSW. Government Printer, Sydney.

Costin, A.B., 1955. Alpine soils in Australia with reference to conditions in Europe and New Zealand. Eur. J. Soil Sci. 6 (1):35-50. https://doi.org/10.1111/j.1365-2389.1955. tb00828.x.

Costin, A.B., Hallsworth, E.G., Woof, M., 1952. Studies in pedogenesis in New South Wales III. The alpine humus soils. Eur. J. Soil Sci. 3 (2):190-218. https://doi.org/10.1111/ j.1365-2389.1952.tb00643.x. 
Crawford, J., Cohen, D.D., Stelcer, E., Atanacio, A.J., 2017. Long term fine aerosols at the Cape Grim global baseline station: 1998 to 2016. Atmos. Environ. 166, 34-46.

Doney, S.C., Mahowald, N., Lima, I., Feely, R.A., Mackenzie, F.T., Lamarque, J.-F., Rasch, P.J. 2007. Impact of anthropogenic atmospheric nitrogen and sulfur deposition on ocean acidification and the inorganic carbon system. Proc. Natl. Acad. Sci. U. S. A. 104 (37) $14580-14585$

Draxler, R., Stunder, B., Rolph, G., Stein, A., Taylor, A., 2016. HYSPLIT4 USER's GUIDE Version 4 - Last Revision: February 2016. Retrieved from. https://www.arl.noaa.gov/documents/reports/hysplit_user_guide.pdf.

Dredge, J., Fairchild, I.J., Harrison, R.M., Fernandez-Cortes, A., Sanchez-Moral, S., Jurado, V., Gunn, J., Smith, A., Spötl, C., Mattey, D., Wynn, P.M., Grassineau, N., 2013. Cave aerosols: distribution and contribution to speleothem geochemistry. Quat. Sci. Rev. 63, 23-41.

Frappier, A.B., 2006. Empirical Orthogonal Function Analysis of Multivariate Stalagmite Trace Element Data: Detecting the 1982 El Chichón Volcanic Eruption, Archives of Climate Change in Karst. 10. Karst Waters Institute Special Publication, pp. 113-115.

Frisia, S., Borsato, A., Fairchild, I.J., Susini, J., 2005. Variations in atmospheric sulphate recorded in stalagmites by synchrotron micro-XRF and XANES analyses. Earth Planet. Sci. Lett. 235 (3-4), 729-740.

Fujita, E.M., Campbell, D.E., Arnott, W.P., Chow, J.C., Zielinska, B., 2007. Evaluations of the chemical mass balance method for determining contributions of gasoline and diesel exhaust to ambient carbonaceous aerosols. J. Air Waste Manage. Assoc. 57 (6), 721-740.

Green, K., Pickering, C., 2002. A Scenario for mammal and bird diversity in the Snowy Mountains of Australia in relation to climate change. Mountain Biodversity: A Global Assessment. Parthenon, New York and London, pp. 239-247.

Hesse, P.P., 1994. The record of continental dust from Australia in Tasman Sea sediments Quat. Sci. Rev. 13 (3), 257-272.

Hesse, P.P., McTainsh, G.H., 2003. Australian dust deposits: modern processes and the Quaternary record. Quat. Sci. Rev. 22 (18-19), 2007-2035.

Hopke, P.K., Ito, K., Mar, T., Christensen, W.F., Eatough, D.J., Henry, R.C., Kim, E., Laden, F. Lall, R., Larson, T.V., Liu, H., Neas, L., Pinto, J., Stölzel, M., Suh, H., Pattero, P., Thurston, G.D., 2006. PM source apportionment and health effects: 1 . Intercomparison of source apportionment results. Journal of Exposure Science and Environmental Epidemiology. 16 (3), 275-286.

Jickells, T., 1995. Atmospheric inputs of metals and nutrients to the oceans: their magnitude and effects. Mar. Chem. 48 (3-4), 199-214.

Kasischke, E.S., Penner, J.E., 2004. Improving global estimates of atmospheric emissions from biomass burning. J. Geophys. Res. Atmos. 109:D14. https://doi.org/10.1029/ 2004JD004972.

Kaufman, L., Rousseeuw, P.J., 2005. Finding Groups in Data: an Introduction to Cluster Analysis. John Wiley \& Sons, Inc., New Jersey, p. 368.

Kohfeld, K.E., Harrison, S.P., 2001. DIRTMAP: the geological record of dust. Earth Sci. Rev. $54(1-3), 81-114$

Kristensen, L.J., 2015. Quantification of atmospheric lead emissions from 70 years of leaded petrol consumption in Australia. Atmos. Environ. 111, 195-201

Likens, G.E., 2010. The role of science in decision making: does evidence-based science drive environmental policy? Front. Ecol. Environ. 8 (6):e1-e9. https://doi.org/ 10.1890/090132.

Mahowald, N., 2011. Aerosol indirect effect on biogeochemical cycles and climate. Science 334 (6057), 794-796.

Malm, W.C., Sisler, J.F., Huffman, D., Eldred, R.A., Cahill, T.A., 1994. Spatial and seasonal trends in particle concentration and optical extinction in the United States. J. Geophys. Res.-Atmos. 99 (D1), 1347-1370.

Marx, S.K., Kamber, B.S., McGowan, H.A., 2008. Scavenging of atmospheric trace metal pollutants by mineral dusts: inter-regional transport of Australian trace metal pollution to New Zealand. Atmos. Environ. 42 (10), 2460-2478.

Marx, S.K., Kamber, B.S., McGowan, H.A., Zawadzki, A., 2010. Atmospheric pollutants in alpine peat bogs record a detailed chronology of industrial and agricultural development on the Australian continent. Environ. Pollut. 158 (5):1615-1628. https://doi org/10.1016/j.envpol.2009.12.009.

Marx, S.K., Kamber, B.S., McGowan, H.A., Denholm, J., 2011. Holocene dust deposition rates in Australia's Murray-Darling Basin record the interplay between aridity and the position of the mid-latitude westerlies. Quat. Sci. Rev. 30 (23-24):3290-3305. https://doi.org/10.1016/i.quascirev.2011.07.015.

Mitchell, R.M., Campbell, S.K., Qin, Y., 2010. Recent increase in aerosol loading over the Australian arid zone. Atmos. Chem. Phys. 10 (4):1689-1699. https://doi.org/ 10.5194/acp-10-1689-2010.

Möller, D., 1990. The $\mathrm{Na} / \mathrm{Cl}$ ratio in rainwater and the seasalt chloride cycle. Tellus B. 42 (3), 254-262.

Nalbandian, H., 2012. Trace Element Emissions From Coal. Report CCC/203. IEA Coal Research, London, UK 89 pp.

Nicholls, N., 2005. Climate variability, climate change and the Australian snow season. Aust. Meteorol. Mag. 54 (3), 177-185.

NPI, 2017. http://www.npi.gov.au (last access: October 2017).

Paatero, P., 2010. User's Guide for Positive Matrix Factorization Programs PMF2 and PMF3, Part 1: Tutorial. University of Helsinki, Finland.

Paatero, P., Tapper, U., 1994. Positive matrix factorization: a non-negative factor model with optimal utilization of error estimates of data values. Environmetrics 5 (2): 111-126. https://doi.org/10.1002/env.3170050203.

Paton-Walsh, C., Smith, T.E.L., Young, E.L., Griffith, D.W., Guérette, É.-A., 2014. New emission factors for Australian vegetation fires measured using open-path Fourier transform infrared spectroscopy - part 1: methods and Australian temperate forest fires. Atmos. Chem. Phys. 14 (20):11313-11333. https://doi.org/10.5194/acp-14-11313-2014.

Pickering, C., Hill, W., Green, K., 2008. Vascular plant diversity and climate change in the alpine zone of the Snowy Mountains, Australia. Biodivers. Conserv. 17 (7) 1627-1644.
Pope III, C.A., Ezzati, M., Dockery, D.W., 2009. Fine-particulate air pollution and life expectancy in the United States. N. Engl. J. Med. 360 (4), 376-386.

Pöschl, U., 2005. Atmospheric aerosols: composition, transformation, climate and health effects. Angew. Chem. Int. Ed. 44 (46):7520-7540. https://doi.org/10.1002/ anie.200501122.

Prospero, J.M., Lamb, P.J., 2003. African droughts and dust transport to the Caribbean: climate change implications. Science 302 (5647), 1024-1027.

Prospero, J.M., Ginoux, P., Torres, O., Nicholson, S.E., Gill, T.E., 2002. Environmental characterization of global sources of atmospheric soil dust identified with the Nimbus 7 Total Ozone Mapping Spectrometer (TOMS) absorbing aerosol product. Rev. Geophys. 40 (1):1002. https://doi.org/10.1029/2000RG000095.

Rea, D.K., 1994. The paleoclimatic record provided by eolian deposition in the deep sea: the geologic history of wind. Rev. Geophys. 32 (2), 159-195.

Ridley, H.E., Asmerom, Y., Baldini, J.U.L., Breitenbach, S.F.M., Aquino, V.V., Prufer, K.M., Culleton, B.J., Polyak, V., Lechleitner, F.A., Kennett, D.J., Zhang, M., Marwan, N., Macpherson, C.G., Baldini, L.M., Xiao, T., Peterkin, J.L., Awe, J., Haug, G.H., 2015. Aerosol forcing of the position of the intertropical convergence zone since AD 1550. Nat. Geosci. 8 (3):195-200. https://doi.org/10.1038/ngeo2353.

Rosenfeld, D., 2000. Suppression of rain and snow by urban and industrial air pollution. Science 287 (5459):1793-1796. https://doi.org/10.1126/science.287.5459.1793.

Rotstayn, L.D., Keywood, M.D., Forgan, B.W., Gabric, A.J., Galbally, I.E., Gras, J.L., Luhar, A.K., McTainsh, G.H., Mitchell, R.M., Young, S.A., 2009. Possible impacts of anthropogenic and natural aerosols on Australian climate: a review. Int. J. Climatol. 29 (4), 461-479.

Rutlidge, H., Baker, A., Marjo, C.E., Andersen, M.S., Graham, P.W., Cuthbert, M.O., Rau, G.C., Roshan, H., Markowska, M., Mariethoz, G., Jex, C.N., 2014. Dripwater organic matter and trace element geochemistry in a semi-arid karst environment: implications for speleothem paleoclimatology. Geochim. Cosmochim. Ac. 135, 217-230.

Shao, Y., Wyrwoll, K.H., Chappell, A., Huang, J., Lin, Z., McTainsh, G.H., Mikami, M., Tanaka, T.Y., Wang, X., Yoon, S., 2011. Dust cycle: an emerging core theme in earth system science. Aeolian Res. 2 (4), 181-204.

Shiga, Y., Greene, R.S.B., Scott, K.M., Stelcer, E., 2011. Recognising terrestrially-derived salt $(\mathrm{NaCl})$ in SE Australian dust. Aeolian Res. 2 (4):215-220. https://doi.org/10.1016/j. aeolia.2011.02.003.

Sigl, M., Winstrup, M., McConnell, J.R., Welten, K.C., Plunkett, G., Ludlow, F., Büntgen, U., Caffee, M., Chellman, N., Dahl-Jensen, D., Fischer, H., Kipfstuhl, S., Kostick, C., Maselli, O.J., Mekhaldi, F., Mulvaney, R., Muscheler, R., Pasteris, D.R., Pilcher, J.R., Salzer, M., Schüpbach, S., Steffensen, J.P., Vinther, B.M., Woodruff, T.E., 2015. Timing and climate forcing of volcanic eruptions for the past 2500 years. Nature 523 (7562):543-549. https://doi.org/10.1038/nature14565.

Simonson, R.W., 1995. Airborne dust and its significance to soils. Geoderma 65, 1-2), $1-43$.

Slatyer, R., 2010. Climate change impacts on Australia's alpine ecosytems. The ANU Undergraduate Research Journal. 2, 17.

Squizzato, S., Masiol, M., Brunelli, A., Pistollato, S., Tarabotti, E., Rampazzo, G., Pavoni, B., 2013. Factors determining the formation of secondary inorganic aerosol: a case study in the Po Valley (Italy). Atmos. Chem. Phys. 13 (4), 1927-1939.

Stein, A.F., Draxler, R.R., Rolph, G.D., Stunder, B.J.B., Cohen, M.D., Ngan, F., 2015. NOAA's HYSPLIT atmospheric transport and dispersion modeling system. Bull. Am. Meteorol. Soc. 96 (12):2059-2077. https://doi.org/10.1175/BAMS-D-14-00110.1.

Sullivan, R.C., Moore, M.J.K. Petters, M.D., Kreidenweis, S.M., Roberts, G.C., Prather, K.A., 2009. Effect of chemical mixing state on the hygroscopicity and cloud nucleation properties of calcium mineral dust particles. Atmos. Chem. Phys. 9 (10):3303-3316. https://doi.org/10.5194/acp-9-3303-2009.

Suni, T., Kulmala, M., Hirsikko, A., Bergman, T., Laakso, L., Aalto, P.P. Leuning, R., Cleugh, H. Zegelin, S., Hughes, D., van Gorsel, E., Kitchen, M., Vana, M., Hõrrak, U., Mirme, S., Mirme, A., Sevanto, S., Twining, J., Tadros, C., 2008. Formation and characteristics of ions and charged aerosol particles in a native Australian Eucalypt forest. Atmos. Chem. Phys. 8 (1):129-139. https://doi.org/10.5194/acp-8-129-2008.

Tadros, C.V., Treble, P.C., Baker, A., Fairchild, I., Hankin, S., Roach, R., Markowska, M., McDonald, J., 2016. ENSO-cave drip water hydrochemical relationship: a 7-year dataset from south-eastern Australia. Hydrol. Earth Syst. Sci. 20 (11):4625-4640. https://doi.org/10.5194/hess-20-4625-2016.

Taha, G., Box, G.P., Cohen, D.D., Stelcer, E., 2007. Black carbon measurement using laser integrated plate method. Aerosol Sci. Technol. 41 (3), 266-276.

Ten Harkel, M.J., 1997. The effects of particle-size distribution and chloride depletion of sea-salt aerosols on estimating atmospheric deposition at a coastal site. Atmos. Environ. 31 (3), 417-427.

Viana, M., Kuhlbusch, T.A.J., Querol, X., Alastuey, A., Harrison, R.M., Hopke, P.K., Winiwarter, W., Vallius, M., Szidat, S., Prévôt, A.S.H., Hueglin, C., Bloemen, H., Wahlin, P., Vecchi, R., Miranda, A.I., Kasper-Giebl, A., Maenhaut, W., Hitzenberger, R., 2008. Source apportionment of particulate matter in Europe: a review of methods and results. J. Aerosol Sci. 39 (10), 827-849.

Walker, P.H., Costin, A.B., 1971. Atmospheric dust accession in South-Eastern Australia. Aust. J. Soil Res. 9 (1), 1-5.

WHO, 2006. http://www.euro.who.int/document/e90038.pdf (last access: 27 November 2017).

Yamasoe, M.A., Artaxo, P., Miguel, A.H., Allen, A.G., 2000. Chemical composition of aerosol particles from direct emissions of vegetation fires in the Amazon Basin: water-soluble species and trace elements. Atmos. Environ. 34 (10):1641-1653. https://doi.org/ 10.1016/S1352-2310(99)00329-5.

Zhou, Y., Levy, J.I., 2007. Factors influencing the spatial extent of mobile source air pollution impacts: a meta-analysis. BMC Public Health 7 (89):1-11. https://doi.org/ 10.1186/1471-2458-7-89.

Zhu, Y., Hinds, W.C., Kim, S., Sioutas, C., 2002. Concentration and size distribution of ultrafine particles near a major highway. J. Air Waste Manage. Assoc. 52 (9):1032-1042. https://doi.org/10.1080/10473289.2002.10470842. 